\title{
STUDY ON SATISFACTION LEVEL OF EXPORTERS AS A SUBSET OF EXPORT PROMOTION- THE MULTI-METHOD STUDY ON CONCOR
}

\author{
Prashant Kumar Pandey \\ Amity University, India \\ E-mail: prashantgreat97@gmail.com \\ Praveen Kumar Pandey \\ Sharda University, India \\ E-mail: praveen.pandey2022@gmail.com \\ Submission: 5/17/2020 \\ Revision: $7 / 3 / 2020$ \\ Accept: 8/26/2020
}

\section{ABSTRACT}

The purpose of the paper is to understand the effect of the services offered by the CONCOR on the satisfaction level of the exporters and the importers, which at first, requires the comprehensive understanding of the services and the best initiatives that are been taken the CONCOR to influence the satisfaction level of the exporters and importers. This paper is based on the deductive approach which includes building up a hypothesis (or hypotheses) in view of existing literature, and afterward outlining an exploration strategy to test the hypothesis (or, hypotheses). After analysis, it has been found by the authors that the level of satisfaction of the exporters and importers is been influenced by the services offered by CONCOR and the years of engagement that the traders have with CONCOR. Also, the satisfaction level that the traders have with the add-on benefits such as discount schemes or e-filling, is very high which shows the happiness among the traders from the services of CONCOR. Through this study, CONCOR can get the ideal services that are been provided with the objective of export promotion and also the possible flaws in services can be redesigned and can also be enhanced through aggressiveness. The study is limited to the data collected from the CONCOR, Tughlakabad. Through this study, export promotion agencies including CONCOR can get the ideal services that is been provided with the objective of export promotion, and also the possible flaws in services can be redesigned and can also be enhanced through aggressiveness. 
DOI: 10.14807/ijmp.v12i5.1346

Keywords: CONCOR, Exporters, Initiatives, ICD, Satisfaction, Importer.

\section{JEL Classification-F23}

\section{INTRODUCTION}

Export and the foreign trade policy is like the motor of monetary development of any nation which presents the possibility of new innovations, demands, and gathers capital. From the perspective of these many developing nations, the world had started the procedure of making monetary changes in their economies amid the 1980s. India like other nations amid the 1990s has propelled that reforms in its economy, for example, in the financial segment, social part, trade division, public segment, and so forth in the form of globalization and the other policies in the given sectors.

The emergence of the World Trade Organization (WTO) has in a general sense affected the financial state of worldwide business the world over. The monetary methodologies of nations are at risk which required the existence of more grounded principles of worldwide exchange under the new managerial framework that came into existence after the Uruguay Round of multilateral agreements (Gururaj, et al., 2016).

An extension in export procedures may incite a wide development in progress and running with a fall in the unemployment rate. Worldwide trade exchange moreover considers the purchase of capital items from outside countries and opens an economy to headway in innovation achieved far and wide (Nair, 2012).

A South Asian developing nation like India has promoted export as methods for promoting financial growth, in course of its struggle for transforming the domestic economy, evacuating or streamlining import limitations, ensuring political stability, empowering investment and lightening poverty, which ought to likewise enhance output level and lead, in time, to advance progression of export (Nair, 2012).

India has encountered an expansion in exports, national output, and capital formation, alongside some unpredictable terms of trade which, in conjunction with the nation's growth designs, would propose that dynamic connections should exist between exports, national output, capital formation and terms of negotiation.

With a particular extreme objective to export through the outskirts of any country like India, the wonders of export development have an especially colossal part. Export development is a pre-condition for financial development and moreover to advance an independent and selfproducing economy. 
DOI: 10.14807/ijmp.v12i5.1346

The export development will be useful from numerous perspectives. Regardless of anything else, it will be important in removing the hazardous position of adjustment of exchange. Moreover, it will be helpful in giving markets to particular items and growing nearby markets for certain unique products.

Also, the export development will outline the favourable circumstances for the satisfaction of our improvement ventures and budgetary game plan. Taking everything into account, the export development will render the benefits of expansive scale generation open to the producers which, in turn, will diminish the cost of assembling invigorating further the export development base (Nair, 2012).

ICD and the dry ports related readings have been completed with an emphasis on the developed countries yet less has been finished as for developing countries regardless of their expanding job in the worldwide SCM. Significant findings by (Roso, 2008; Roso, et al., 2008; Notteboom, 2008; Rodrigue, et al., 2010; Veenstra, et al., 2012; Wilmsmeier, et al., 2011) to make reference to yet a couple of focused on Europe and North America. (Padilha \& Ng, 2012) turned their consideration on Brazil while (Garnwa, et al., 2009) made a relative report on dry ports including Nigeria. In any case, look into on advancement and mix of ICDs in the supplychain frameworks covering developing nations and India, specifically, is as yet confined and should be investigated moreover.

This paper focuses on the determination of the services offered by ICDs which all have the relation with maximization of satisfaction of the exporters. Also, the best practices and the initiatives that are been taken by the CONCOR to boost up the satisfaction level of the exporters by providing them additional ease on for the operations. Also, the authors made the structured questionnaire in order to collect the background information and the operational information from the exporters to get an effective picture of their satisfaction level of the exporters that they have while operating with ICDs.

\subsection{Limitation of the study}

- The Scope of Study contemplate has been finished by choosing one of all ICDs, i.e., ICD, Tughlakabad.

- Exploratory and Qualitative Research has been done to comprehend the administrations gave by the Export Promotion Councils.

\subsection{Managerial implications}

i. ICDs to redesign their administrations and enhance their aggressiveness. 
DOI: 10.14807/ijmp.v12i5.1346

ii. Exporters will pick up learning and data for better execution.

iii. Ministry of Commerce to take restorative strategy measures.

\subsection{Need for the study}

A strong infrastructure framework is an essential component in the process of making the performance of export better (PHD Research Bureau, 2017). World Bank report, LPI assesses execution of nations on trade logistics on 6 key measurements, such as the effectiveness of the clearance procedure, nature of trade and logistics-related framework (e.g. ports, railways, roadways, IT), in which they were before on $58^{\text {th }}$ rank and now on $36^{\text {th }}$ rank, nature of transportation administrations, in which they were before on $52^{\text {nd }}$ rank and now on $32^{\text {nd }}$ rank, capacity to track consignments, in which they were before on $57^{\text {th }}$ rank and now on $33^{\text {rd }}$ rank, and convenience of shipments in achieving goal inside the planned or expected conveyance time. India hopped 19 spots to move to the 35th rank in the year 2016 mirroring the enhanced effectiveness in this part (The World Bank, 2018).

Also, WEF's GCI evaluates the intensity of nations to give understanding to drivers of their profitability and success. GCI scores are ascertained on the premise of 12 classes called 'pillars of the competition' which covers both business and social pointers. It incorporates columns, for example, organizations, framework, wellbeing, and essential training, work showcase proficiency, money related market advancement, innovative preparation, and market estimate. It is vital to manage this force and particular exercises for exchange assistance will additionally empower our development. India was set at 40th rank among 137 nations in the World Economic Forum's (WEF) GCI 2017-18 (UNI, 2018; WEF, 2018).

Inland Container Depots have a complex part to play as an impetus in promoting exports (UNESCAP, 2006; Pettit \& Beresford, 2009). It does not just develop a stage for the exporters to redress their issues and proposals to the concerned authority yet additionally infiltrate new markets for Indian products. ICDs are the NPO association and defining up objectives for the normal enthusiasm of individuals focusing on the Country's image. Having a wide global system, ICDs give complementary trade preferment exercises to the advantages of Indian exporters. ICDs and the dry ports related readings have been completed with an emphasis on the developed countries yet less has been finished as for developing countries regardless of their expanding job in the worldwide SCM.

\subsection{Objective Of The Study}

- To understand the major services and the initiatives that are offered by CONCOR 
DOI: 10.14807/ijmp.v12i5.1346

- To understand the role of services of CONCOR in the maximization of satisfaction of exporters.

- To evaluate exporter-importers' satisfaction level mainly on the basis of services.

- Suggestions and recommendations for enhancing the efficiency and effectiveness of ICDs.

\section{LITERATURE EVALUATION}

\subsection{Background of the study}

As far back as globalization changed the transport division the most, national limits have turned out to be porous to the entrance by trade, making the requirement for versatile transport arrangements. Inter-modalism service and the containerization service were the byproducts of this time and they were ready to transform in the transportation of the "cargo", transporting it "flawlessly" all the way through the ocean and the land or roadways. Merchandise should be ecstatic by the Lorries to the point of export port, emptied in the port's warehouse and afterward gets reloaded on the cargo ship "part by part”.

Malcolm McLean gave a concept of containerization (Pearson, 2001) which changed the fundamentals of the cargo transportation by institutionalizing the size of the containers and at that same time, enhancing the profitability of ports by automating the handling of container conveying "cargo" ships and diminishing their dealing with to a couple of hours as it were. As the concept of containerization came to remain for "cargo care”, it developed significantly all over the world.

The strategic activity of Indian Railways to containerize the freight transport put India on the multi-modular guide without precedent for 1966 (United Nations, 2003). As the continental distances from India are very far (very nearly $3000 \mathrm{~km}$ from North to South and East to West), so, in that case, rail transport can be said as the less expensive alternative for any payload over long separations and also in case of medium distances, particularly if the cost of inter-modular transfers could be lessened. The containerized multi-modular way toentryway transport gave the perfect answer to the above issue. This was the basic thought that Indian Railways saw while entering the market for moving way to-entryway household load in special DSO holders began by 1966.

\subsection{Worldwide Services And Facilities}

LCL Consolidation-The method of LCL consolidation incorporates the maximization of not as much as compartment stack from an Inland Container Deport to an assigned 
INDEPENDENT JOURNAL OF MANAGEMENT \& PRODUCTION (IJM\&P)

http://www.ijmp.jor.br

v. 12, n. 5, July-August 2021

ISSN: 2236-269X

DOI: 10.14807/ijmp.v12i5.1346

"merchant's point" terminal under customs seals, all the more frequently in a neighbourhood holder or something to that effect. At the chose port terminal, the pre-fixed holders are opened and the load re-tackled an objective wise commence without being subjected to re-evaluation by Customs people. For instance, Exporter masterminded in Colombo, Sri Lanka has a shipment to be traded to abroad buyer in Antwerp by means of the ocean - say concerning 4cbm of $1200 \mathrm{kgs}$. As indicated by your cost of shipping in a full holder, the heap isn't worth as the total sum and volume are too little to stack into a compartment. This is called LCL shipment, infers Less Container Cargo shipment. Such services gave by ICD are greatly alluring the clients. (lcllogistix.com, n.d.)

Cool Chain/Reefer Services-Presently, in this world, the reefer-mass fleet has experienced an irreversible abatement, while the reefer compartment armada has exhibited a constant rate of development (Parola \& Giulia, 2010). This incorporates offering transportation to transient things from source to end-customer while keeping up a particular temperature en route. ICD is giving principal rail-based reefer benefits among Delhi and Mumbai and could get into giving chilly chains by making two or three-game plan designs that would broaden its market closeness. These would generally include, having a tie-up with an overall major, preferably with creating a country associated with both development and value obligation for gaining the crucial equipment, organizing terminal to modern office transport, refrigerated dissemination focuses where required, and movement, while keeping up the temperatures controlled conditions, and travel commitment and identifying sensible ways for specific things (CONCOR).

This will require tying up with manufacturers and clients uninhibitedly or tie-up with sustenance taking care of major to spread its things. Return trips wherever conceivable make cold chain tasks more beneficial and all over demonstrates the differentiation between standard venture and misfortunes (CONCOR). Cold Chain/Reefer Services is an administration that gives the cold stockpiling to different perishable products. This office profitably satisfies the customer's (i.e., exporters) expectations to keep satisfaction level high (starzgazer, n.d.).

Production line Stuffing and De-Stuffing-Keeping in time with the global example, containers are as of now embarking to shipper's units more for cargo stuffing/de-stuffing, as against the general example 10 years sooner, when an expansive bit of the heap was getting stuffed/de-stuffed at the ports/ICDs or at the plant which should be settled under the supervision of custom officer (Central Board of Excise and Customs, 2017). CONCOR's ICDs are presently totally furnished to give the basic "on-carriage" and "pre-carriage" services to shippers, along these lines, totally discarding any heap dealing with in transit. While such administrations are 
INDEPENDENT JOURNAL OF MANAGEMENT \& PRODUCTION (IJM\&P)

http://www.ijmp.jor.br

v. 12, n. 5, July-August 2021

ISSN: 2236-269X

DOI: 10.14807/ijmp.v12i5.1346

much of the time available through private channels, ICD in like manner has a course of action that gets ready for giving such offices on-ask for a particular rates for their customers.

E-Filing office at ICD- E-Filing administration is an online application for EXIM zones being operational at Terminal/Inland Container Depot of CONCOR. The objective of this product is to give one phase to the entire import/export exchange to perform online all their business trades with EXIM territories from wherever. This particular service can be used as the advertising methodology for attracting the exporters towards the ICDs (Gregory, et al., 2007) (Nasah, et al., 2012).

Through this product, any merchant/exporter/shipping administrator can record his reports including charging and take basic printouts. Diverse Queries and Reports are moreover part of this electronic programming to screen container at each stage and besides to find due add up to be paid to ICD. This administration engages customers like Shipping lines, Importers, Exporters, and CHA's to record the required files online for process and take imperative printouts of arranged yield through the web from wherever without physically coming to terminal/ICD. Electronic Signatures have been composed of e-filling to impact the system more to anchor. This engages our customers to get to information concerning their shipments by strategies for the site (CONCOR, n.d.). This empowers the exporters to have an administration of CONCOR to an ever-increasing extent.

Hub and Spoke Services- The places where CONCOR faces challenges from the private transport companies were the price and the time for transportation. CONCOR has a belief that in a normal course of business, they are able to tackle the challenge of the price of transportation of heavy cargoes from one place to the other given place and also, the truck operators under the company offers some sort of flexibility of timing for any given shipment (Liu \& Moizer, 2012).

Trucks such as Volvo trucks immensely lowered down the transit time of the shipment. Such a massive change is giving competition to the rail transit time and also has increased the level of competition in the market. The phrase "hub and spoke" came into existence to mix the advantages of rail transport as well as road transport. If both conditions, i.e., international orders as well as national orders, taken into concern with the objective of making the process of both the orders feasible for the exporters or importers, then in that case, the hub and spoke service of CONCOR can be considered as the most effective one (Konings, et al., 2013).

Such kind of operations includes the mixture of both rail and road transportation wherever which is applicable best. At present point in time, ICD in Tughlakabad is offering the best terminal hub for the other terminals like Moradabad, Ludhiana, etc. Also, ICD Khatuwas 
DOI: 10.14807/ijmp.v12i5.1346

has emerged as a hub for transhipment orders between North India and West India (CONCOR, n.d.).

Add up to Logistics Services add up to coordination, like that of promoting, has been to some degree untouchable to regular Indian business ethos. Coordination implies the mix of no less than two activities with the ultimate objective of arranging, executing, and controlling the successful stream of rough materials, in-process stock and completed stock from the reason for starting point utilized for the motivation behind utilization (Soinio, et al., 2012).

Purchaser reliability is basic for coordination's associations searching for high ground since they comprehend that if they don't satisfy the wants of customers, their place will be taken by various associations whose activities will be more centred on client's wants (Kavaliauskienè, et al., 2014). Transportation is regularly the single greatest cost in the coordination method. For the advancement of the business, CONCOR expects to cut a claim to fame for itself as the provider of outsider coordination's organization.

\subsection{Assessment of consumer loyalty level through the services}

Components driving the consumer loyalty which all are outfitted by ICD, Tughlakabad (CONCOR): -

$>$ Online Information and Container Tracking-ICD, Tughlakabad has the administration by which the exporter can get all the indispensable information and can track the information related to the dispatch through the web as the ICD keeps up the database for their customers.

$>$ Container Repair and Cleaning Facilities-ICD gives the ideal and safe container for their exporters with the objective that the items secured in that holder could remain until the period of de-stuffing the holder.

$>$ Fumigation of Cargo/Containers-This is an especially sensible advance towards the route toward keeping the compartment clean. This infers the nuisance control is done after each reserved time period. This gives the exporters the vibe of keeping the stock in a protected position in the compartment.

SCM (Supply Chain Management)-The SCM of ICD is clearly superior to each and every other assembling responsible for the supply of stock beginning with one place then onto the following. In this part, ICD de-stuffs the items safely and takes the stock to the objective point sheltered. 
> Door Delivery/Pick Up of Containerized payload- In the wake of stuffing the holder at the plant or at the port, ICD accepts the obligation to take that compartment safely to the goal port and after to the point of the objective, if fused into the bill.

There are various diverse concentrations that incited the satisfaction of the exporters with the ICDs and goad them to convey to a regularly expanding degree. Such concentrations are according to the accompanying pre-deposit accounts, round the clock security at terminals, facilitation of customs clearance, flexible payment arrangements, and also, ICD lead customer satisfaction survey consistently to get criticism from the clients and furthermore make a move to redress/enhance our administrations.

CONCOR had moreover displayed on Company's site "Feedback.com" wherein the customers can get the information and search for cures on their administrations and the offices in the arrangement available under the menu "Client Feedback Facility". Provoke action on these recognitions/proposition is taken to upgrade the idea of their administrations to the clients.

Also, CONCOR adopts initiatives for the purpose of making changes in the services offered by the ICD to the exporters and with the mindset to influence the satisfaction level of the exporters operating over there. Such initiatives can be summarized as multi-tier assembling in the warehouse, payment of CONCOR dues through an electronic medium, refund - Direct transfer of reimbursement of drawback amount through DBT, regular auction (approx. 6 times in a year), EDI interfacing with Customs, kiosks for accepting the queries of exporters at EXIM cell, installation of cameras for having a curb on theft, shipping-bill wise loading of export order is been started, scheme of tatkal delivery for imports, high-value cargo separate stake and last but not the least is offering the SMS facility to the exporters to allow them to track their containers in transit. Proforma of this is "CI- container no." to number 56677 (CONCOR). The above-given parts are directly going about as isolating variables which are enabling the exporters for having an awesome satisfaction.

\subsection{Facility and customer satisfaction}

Satisfaction is impacted in the service case because of the logic which says that customers are the co-producers of the value (Chan et al., 2010) rather than merely being receivers and a company just plays the role of a facilitator. So, if they get a chance to get involved in high-quality service at a relatively low cost, the satisfaction will start to reduce and ultimately the customer switches the brand (Chan et al., 2010). 
DOI: 10.14807/ijmp.v12i5.1346

Along these lines, it can be said that satisfaction is the ultimate precept that every customer wants to achieve and the premise for the same will be the customer's involvement in the service process (Pandey \& Malik, 2017). Customer involvement provides value not only to the customer-related issues but to the company in general (Chan et al., 2010; Yim et al., 2012).

According to Chen and Chen (2010), loyalty is shown by the customers when they are highly satisfied with the services in the long-term (Chen \& Chen, 2010). Such a case is usually demanded by a service supplier (Chan et al., 2010) because loyal customers can do further advertisement through word of mouth (WOM) into their reachable community (Casidy \& Wymer, 2015) and in a business where the product is intangible and can mainly be felt through advertisements and feedbacks, WOM plays the utmost role (Pandey, et al., 2020).

\section{METHODOLOGICAL PROCEDURES}

\subsection{Hypothesis}

Based on the above review of literature, the following hypothesis can be postulated:

1) There is no association between years of engagement and level of satisfaction of the service offered by CONCOR.

2) There is no significant difference between the services offered* and the level of satisfaction.

3) There is no significant difference between commercial facilities ${ }^{* *}$ and level of satisfaction.

(*)- Multi-modal transportation, LCL Consolidation, Cold-Reefer services, and Aircargo movement, Factory-stuffing service only.

(**)- Discount schemes and E-filling facilities only.

\subsection{Methods}

\subsubsection{Sample and procedures}

The survey is being conducted through the structured, multiple-choice, and close-ended questionnaire in order to collect experimental data from the customer, i.e., exporters and importers, of CONCOR. The survey was based on non-probability convenience sampling and snowball sampling due to the paucity of time and resources. The questions under the questionnaire are been made based on the works of the literature analyzed.

In total 160 questionnaire forms were distributed, but finally, 152 responses were selected after scrutinizing the incomplete forms, means approx. 95\% yielded out of total. 
DOI: 10.14807/ijmp.v12i5.1346

Besides, secondary data is used which gave the point by point information about the exercises including setting up, parts, administrations, and offices offered by the CONCOR from libraries, yearly reports, monetary review, and diaries. For this purpose, 50 works of literature are used.

\subsubsection{Measures}

In order to confirm the content validity, the measures and constructs were adopted from the existing scales. All questions, excluding demographic questions, are asked on the basis of Likert scale, means (ranging from 'Most Important' to 'Not at all important') 'Most Important' was assigned '5' points while 'Not at all important' was assigned ' 1 ' point.

The independent variables are years of engagement, services offered, and commercial facilities. Services such as Multi-modal transportation, LCL Consolidation, Cold-Reefer services, and Air-cargo movement, Factory-stuffing service are included and commercial facilities such as Discount schemes and E-filling facility are included The construct items were prepared in English for distribution in the Tughlakabad region of New Delhi.

\section{ANALYSIS OF RESULT AND DISCUSSION}

The internal consistency reliability is analyzed through Cronbach’s Alpha analysis. The alpha value greater than 0.6 is said to be enough to say that data is reliable (Sekaran \& Bougie, 2016). In order to do an analysis of the data collected from different respondents, SPSS is used in this study, and tests such as Correlation, Chi-square Test is used in this study.For the purpose of statistical analysis, IBM SPSS 20 has been used.

\subsection{1 RELIABILITY ANALYSIS}

Table 1: Reliability Analysis

\begin{tabular}{|c|c|}
\hline \multicolumn{2}{|c|}{ Reliability Statistics } \\
\hline Cronbach's Alpha & N of Items \\
\hline 0.749 & 12 \\
\hline
\end{tabular}

In table 1, it can be said that the data collected is reliable as the author said in 1978 that the alpha value with 0.70 and above is satisfactory for the research work (Nunnally, 1978).

\subsection{Hypothesis Testing}

1) Years of engagement and level of satisfaction

Table 2: Hypothesis 1

\begin{tabular}{|c|c|c|}
\hline \multicolumn{2}{|c|}{ Correlations } \\
\hline Years of & Pearson Correlation & 0.262 \\
\cline { 2 - 3 } engagement & Sig. (2-tailed) & 0.001 \\
\cline { 2 - 3 } & $\mathrm{N}$ & 152 \\
\hline
\end{tabular}


DOI: 10.14807/ijmp.v12i5.1346

From table 2, it is shown that the correlation value is 0.262 , which shows that there is a positive relationship between the years of engagement with CONCOR and the level of satisfaction from the services that are offered by the CONCOR (Ratner, 2009). The p-value (sig. value) is 0.001 which less than the assumed significance level, i.e., 0.05. This means that the author has to reject the null hypothesis. So, it can be said that there is an association between the years of engagement and level of satisfaction of exporters.

2A) Multi-modal transportation and Level of satisfaction.

Table 3: Hypothesis 2a

\begin{tabular}{|c|c|}
\hline \multicolumn{2}{|c|}{ Pearson Chi-Square Tests } \\
\hline Chi-square & 58.461 \\
\hline Df & 4 \\
\hline Sig. & 0.000 \\
\hline
\end{tabular}

After analysing the table 3, it can be said that there is a significant difference between the multi-modal transportation service that is offered by the CONCOR and level of satisfaction from this service. This can be said by the help of p-value that is calculated by SPSS, i.e., $>0.001$, as it is less than the assumed significance level, i.e., 0.05. So, by this, the null hypothesis is rejected and the alternative says that there is a significant difference between the multi-modal transportation service that is offered by the CONCOR and level of satisfaction that is gained by the exporter from this service.

Table 4: Cross Tab Multi-modal vs CONCOR Customers

\begin{tabular}{|l|l|r|r|r|}
\hline \multicolumn{2}{|c|}{} & \multicolumn{3}{|c|}{ CONCOR Customers } \\
\cline { 3 - 5 } \multicolumn{2}{c|}{} & Exporter Only & Importer Only & $\begin{array}{c}\text { Both Exporter } \\
\text { and Importer }\end{array}$ \\
\hline \multirow{4}{*}{\begin{tabular}{l} 
Multi-modal \\
\cline { 2 - 4 }
\end{tabular}} & Extremely Unhelpful & 4 & 3 & 5 \\
\cline { 2 - 5 } & Unhelpful & 1 & 2 & 3 \\
\cline { 2 - 5 } & Somewhat Helpful & 5 & 14 & 18 \\
\cline { 2 - 5 } & Helpful & 9 & 17 & 31 \\
\cline { 2 - 5 } & Extremely Helpful & 5 & 17 & 18 \\
\hline
\end{tabular}

After breaking down the table 4, it can be said that the traders operating in both the exporting and importing are experiencing some sort of satisfaction from the multi-modal service that is offered by CONCOR to them. Also, most of the importers are experiencing satisfaction from the service of multi-modal. This table is further affirming the validation of the Chi-square test.

2B) LCL Consolidation and Level of satisfaction

Table 5: Hypothesis 2b

\begin{tabular}{|c|c|}
\hline \multicolumn{2}{|c|}{ Pearson Chi-Square Tests } \\
\hline Chi-square & 1.179 \\
\hline Df & 4 \\
\hline Sig. & 0.000 \\
\hline
\end{tabular}


DOI: 10.14807/ijmp.v12i5.1346

After analysing the given table 5, it can be said that there is a significant difference between the LCL Consolidation service that is offered by the CONCOR and the level of satisfaction from this service. This can be said by the help of p-value that is calculated by SPSS, i.e., $>0.001$, as it is less than the assumed significance level, i.e., 0.05. So, by this, the null hypothesis is rejected and the alternative says that there is a significant difference between the LCL Consolidation service that is offered by the CONCOR and level of satisfaction that is gained by the exporter from this service.

Table 6: LCL Consolidation vs CONCOR Customers

\begin{tabular}{|l|l|r|r|r|}
\hline \multicolumn{2}{|c|}{} & \multicolumn{3}{|c|}{ CONCOR Customers } \\
\cline { 3 - 5 } \multicolumn{2}{|c|}{} & Exporter Only & Importer Only & $\begin{array}{c}\text { Both Exporter and } \\
\text { Importer }\end{array}$ \\
\hline \multirow{3}{*}{$\begin{array}{l}\text { LCL } \\
\text { Consolidation }\end{array}$} & Extremely Unhelpful & 5 & 1 & 3 \\
\cline { 2 - 5 } & Unhelpful & 1 & 1 & 1 \\
\cline { 2 - 5 } & Somewhat Helpful & 9 & 10 & 9 \\
\cline { 2 - 5 } & Helpful & 6 & 31 & 20 \\
\cline { 2 - 5 } & Extremely Helpful & 3 & 10 & 42 \\
\hline
\end{tabular}

After breaking down the table 6, it can be said that the traders operating in both the exporting and importing are experiencing some sort of satisfaction from the LCL consolidation service that is offered by CONCOR to them. Also, most of the importers are experiencing satisfaction from the service of LCL consolidation. This table is further affirming the validation of the Chi-square test.

2C) Reefer services and Level of satisfaction.

Table 7: Hypothesis 2c

\begin{tabular}{|c|c|}
\hline \multicolumn{2}{|c|}{ Pearson Chi-Square Tests } \\
\hline Chi-square & 94.711 \\
\hline Df & 4 \\
\hline Sig. & 0.000 \\
\hline
\end{tabular}

After analysing the given table 7, it can be said that there is a significant difference between the Reefer services service that is offered by the CONCOR and the level of satisfaction from this service. This can be said by the help of p-value that is calculated by SPSS, i.e., $>0.001$, as it is less than the assumed significance level, i.e., 0.05 . So, by this, the null hypothesis is rejected and the alternative says that there is a significant difference between the Reefer service that is offered by the CONCOR and level of satisfaction that is gained by the exporter from this service.

Table 8: Reefer Service vs CONCOR Customers

\begin{tabular}{|l|c|r|r|r|}
\hline \multicolumn{2}{|c|}{} & \multicolumn{3}{|c|}{ CONCOR Customers } \\
\hline & Exporter Only & Importer Only & $\begin{array}{c}\text { Both Exporter and } \\
\text { Importer }\end{array}$ \\
\hline & Extremely Unhelpful & 5 & 2 & 4 \\
\hline
\end{tabular}


INDEPENDENT JOURNAL OF MANAGEMENT \& PRODUCTION (IJM\&P)

http://www.ijmp.jor.br

v. 12, n. 5, July-August 2021

ISSN: 2236-269X

DOI: 10.14807/ijmp.v12i5.1346

\begin{tabular}{|l|l|r|r|r|}
\hline \multirow{3}{*}{$\begin{array}{l}\text { Reefer } \\
\text { Service }\end{array}$} & Unhelpful & 3 & 1 & 1 \\
\cline { 2 - 5 } & Somewhat Helpful & 5 & 8 & 14 \\
\cline { 2 - 5 } & Helpful & 8 & 27 & 38 \\
\cline { 2 - 5 } & Extremely Helpful & 3 & 15 & 18 \\
\hline
\end{tabular}

After breaking down the table 8, it can be said that the traders operating in both the exporting and importing are experiencing some sort of satisfaction from the reefer service that is offered by CONCOR to them. Also, most of the importers are experiencing satisfaction from the service of reefer. This table is further affirming the validation of the Chi-square test.

2D) Air-Cargo Movement and Level of Satisfaction

Table 9: Hypothesis 2d

\begin{tabular}{|c|c|}
\hline \multicolumn{2}{|c|}{ Pearson Chi-Square Tests } \\
\hline Chi-square & 83.066 \\
\hline Df & 4 \\
\hline Sig. & 0.000 \\
\hline
\end{tabular}

After analysing table 9, it can be said that there is a significant difference between the air-cargo movement that is offered by the CONCOR and the level of satisfaction from this service. This can be said by the help of p-value that is calculated by SPSS, i.e., $>0.001$, as it is less than the assumed significance level, i.e., 0.05. So, by this, the null hypothesis is rejected and the alternative says that there is a significant difference between the air-cargo movement that is offered by the CONCOR and level of satisfaction that is gained by the exporter from this service.

Table 10: Air-cargo movement vs CONCOR Customers

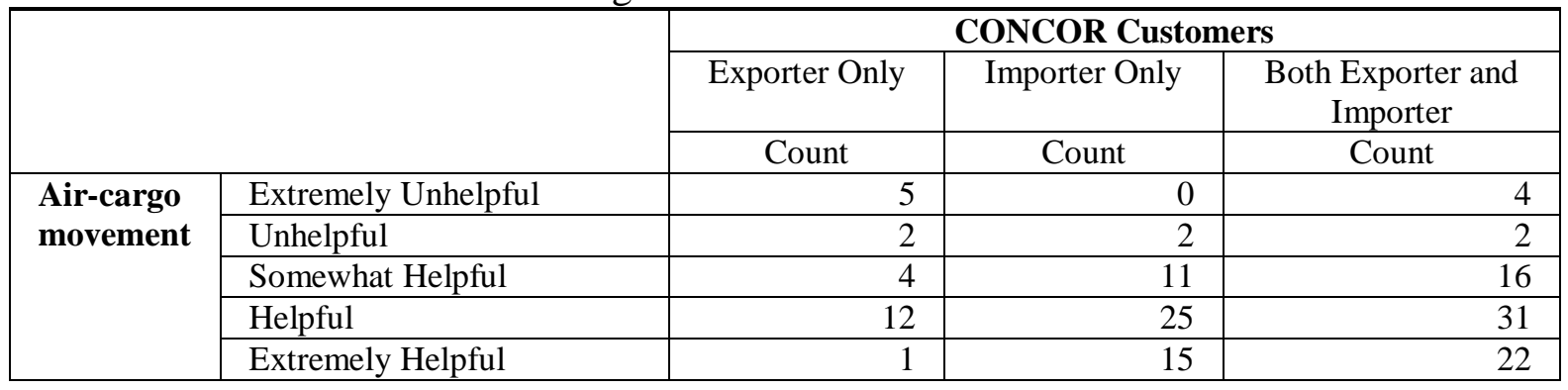

After breaking down the table 10, it can be said that the traders operating in both the exporting and importing are experiencing some sort of satisfaction from the air-cargo movement service that is offered by CONCOR to them. Also, most of the importers are experiencing satisfaction from the service of the air-cargo movement. This table is further affirming the validation of the Chi-square test.

2E) Factory-stuffing and Level of satisfaction

Table 11: Hypothesis 2E 
INDEPENDENT JOURNAL OF MANAGEMENT \& PRODUCTION (IJM\&P)

http://www.ijmp.jor.br

v. 12, n. 5, July-August 2021

ISSN: 2236-269X

DOI: 10.14807/ijmp.v12i5.1346

\begin{tabular}{|c|c|}
\hline \multicolumn{2}{|c|}{ Pearson Chi-Square Tests } \\
\hline Chi-square & 83.197 \\
\hline Df & 4 \\
\hline Sig. & 0.000 \\
\hline
\end{tabular}

After analysing table 11, it can be said that there is a significant difference between the factory-stuffing that is offered by the CONCOR and the level of satisfaction from this service. This can be said by the help of p-value that is calculated by SPSS, i.e., $>0.001$, as it is less than the assumed significance level, i.e., 0.05. So, by this, the null hypothesis is rejected and the alternative says that there is a significant difference between the factory-stuffing that is offered by the CONCOR and level of satisfaction that is gained by the exporter from this service.

Table 12: Factory-stuffing vs CONCOR Customers

\begin{tabular}{|c|c|c|c|c|}
\hline & \multicolumn{3}{|c|}{ CONCOR Customers } \\
\hline & & Exporter Only & Importer Only & $\begin{array}{c}\text { Both Exporter and } \\
\text { Importer }\end{array}$ \\
\hline & & Count & Count & Count \\
\hline Factory- & Extremely Unhelpful & 3 & 3 & 2 \\
\hline stuffing & Unhelpful & 2 & 2 & 1 \\
\hline & Somewhat Helpful & 4 & 13 & 15 \\
\hline & Helpful & 12 & 20 & 34 \\
\hline & Extremely Helpful & 3 & 15 & 23 \\
\hline
\end{tabular}

After breaking down the table 12, it can be said that the traders operating in both the exporting and importing are experiencing some sort of satisfaction from the factory-stuffing service that is offered by CONCOR to them. Also, most of the importers are experiencing satisfaction from the service of factory-stuffing. This table is further affirming the validation of the Chi-square test.

3A) Discount schemes and levels of satisfaction.

Table 13: Hypothesis 3a

\begin{tabular}{|c|c|}
\hline \multicolumn{2}{|c|}{ Pearson Chi-Square Tests } \\
\hline Chi-square & 1.498 \\
\hline Df & 4 \\
\hline Sig. & 0.000 \\
\hline
\end{tabular}

After analysing table 13, it can be said that there is a significant difference between the discount schemes that are offered by the CONCOR and the level of satisfaction from this. This can be said by the help of p-value that is calculated by SPSS, i.e., $>0.001$, as it is less than the assumed significance level, i.e., 0.05. So, by this, the null hypothesis is rejected and the alternative says that there is a significant difference between the discount schemes that are offered by the CONCOR and level of satisfaction that is gained by the exporter from this.

Table 14: Discount schemes vs CONCOR Customers 
DOI: $10.14807 /$ ijmp.v12i5.1346

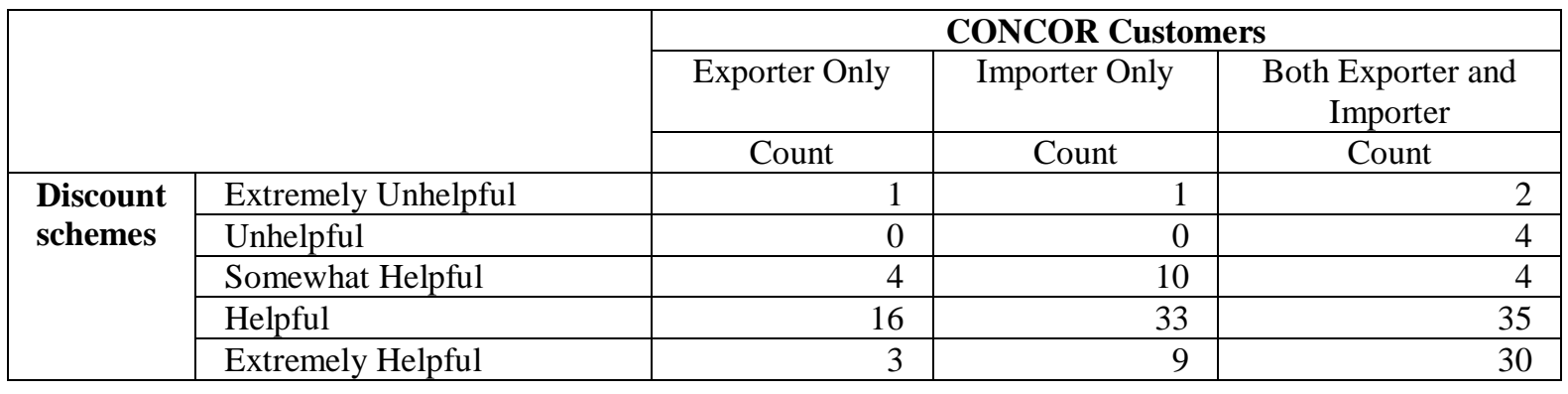

After breaking down the table 14, it can be said that the traders operating in both the exporting and importing are experiencing some sort of satisfaction from the discount schemes that are offered by CONCOR to them. Also, most of the importers are experiencing satisfaction from the discount. This table is further affirming the validation of the Chi-square test.

3B) E-filling facility and Level of satisfaction

Table 15: Hypothesis 3b

\begin{tabular}{|c|c|}
\hline \multicolumn{2}{|c|}{ Pearson Chi-Square Tests } \\
\hline Chi-square & 81.487 \\
\hline Df & 4 \\
\hline Sig. & 0.000 \\
\hline
\end{tabular}

After analysing table 15, it can be said that there is a significant difference between the e-filling facility that is offered by the CONCOR and the level of satisfaction from this service. This can be said by the help of p-value that is calculated by SPSS, i.e., $>0.001$, as it is less than the assumed significance level, i.e., 0.05. So, by this, the null hypothesis is rejected and the alternative says that there is a significant difference between the e-filling facility that is offered by the CONCOR and level of satisfaction that is gained by the exporter from this service.

Table 16: E-filling facility vs CONCOR Customers

\begin{tabular}{|c|c|c|c|c|}
\hline & \multicolumn{3}{|c|}{ CONCOR Customers } \\
\hline & & Exporter Only & Importer Only & $\begin{array}{l}\text { Both Exporter and } \\
\text { Importer }\end{array}$ \\
\hline & & Count & Count & Count \\
\hline & Extremely Unhelpful & 0 & 1 & 1 \\
\hline filling & Unhelpful & 5 & 3 & 2 \\
\hline facility & Somewhat Helpful & 4 & 10 & 19 \\
\hline & Helpful & 13 & 20 & 30 \\
\hline & Extremely Helpful & 2 & 19 & 23 \\
\hline
\end{tabular}

After breaking down the table 16, it can be said that the traders operating in both the exporting and importing are experiencing some sort of satisfaction from the e-filling facility that is offered by CONCOR to them. Also, most of the importers are experiencing satisfaction from the e-filling facility. This table is further affirming the validation of the Chi-square test.

\section{KEY FINDINGS AND DISCUSSION}


INDEPENDENT JOURNAL OF MANAGEMENT \& PRODUCTION (IJM\&P)

http://www.ijmp.jor.br

v. 12, n. 5, July-August 2021

ISSN: 2236-269X

DOI: 10.14807/ijmp.v12i5.1346

The thorough analysis of different works of literature from different sources, it is quite evident to understand that the services offered by CONCOR can help the traders to infiltrate new markets abroad. Such services can be considered as the elevated quality services that will be useful for making the trade agreements and relationship effective and of the long term. Distinctive focus action presented by the Ministry of Commerce under the Foreign Trade Policy primarily concentrates on two specific areas for the expansion of exports out from the nation viz., Market focused exercise and Product-centered exercise with exceptional motivating forces to the exporting group. Despite the fact that this is presented on a short-term basis by the govt. to help those exporters, who endured by virtue of the subsidence in a portion of the developed markets and its resulting impacts.

The findings of the study can be elucidated as the traders, that can be classified as the exporters and the importers, are much satisfied with the service quality that is offered by CONCOR to them. It is also found in the analysis that the years of engagement with CONCOR is directly correlated with that of the level of satisfaction gained by the traders. This is there as because the more the engagement will be with CONCOR, the more will be the knowledge of the process understanding by the company, which will make the processing of the whole of the operations there very convenient for them. Along with this, the effect of add-on benefits such as the discount schemes, etc. on the level of satisfaction was tested by the authors, with the result of which it was found that such schemes have an effect on the satisfaction level of the traders. Such schemes act as the element of boosting the satisfaction level of them.

Central Government support exporters by the method for repaying their piece of costs caused through market development help. Moreover, the Central Government additionally helps the State governments through many plans for which the advantages can be harvested by the exporter group. A state government additionally allocates assets to such infrastructural developments and export assistance agencies and this likewise brings about the upgrading of job-opportunities and financial growth. Both central and state governments are endeavoring hard to advance exports through their nodal organizations. The key outcome ranges are advancing and upgrading the fare exhibitions from the state.

\section{CONCLUSIONS AND RECOMMENDATIONS}

ICDs should take more activities to assist exporters with infiltrating new markets for the Indian saleable products keeping in context of the methodology announcements and moreover guarantee that the activities for the unique focused-activity as per the approaches for 
DOI: 10.14807/ijmp.v12i5.1346

both focused-goods and focused international markets are made available to all the qualified exporters.

Quality is a critical indispensable factor for the things anticipated costs, the complement for getting ready in various associations of "Value Improvement" and controls and the latest innovation preparing should be grasped which will help in "Brand India" thought of the Government of India. For the quality, the exporters who all are being with the CONCOR for several years said that they are much relaxing and convinced with the quality of service that all are provided to them in a due course of either export or import of the said consignment.

Another basic point is that the CONCOR ought to go about as a catalyst for the opportune apportioning of the spurring powers falling under their space. Extra sparks detailed under the extra offices as indicated by the procedure for both focus things and focus markets are affected open to all the qualified exporters to well in time and this will be an extremely influencing factor for the exporters. They should in like manner grasp that any concede happening in the administering of the motivators or deferral in proposing for a comparative will achieve exporters losing trust in the governing body and their declarations.

The CONCOR, furthermore, should engage them in the risk management activities and lightening of dangers in the most revived manner so that the people to impact them to understand that covering the hazard should not be seen as a statutory essential but instead it is for the prosperity of their items. Finally, a positive and incite affirmation by ICDs should be their inspiration for activities as time is a basic factor in worldwide exchange and finally the time is a monetary value.

\section{DECLARATION}

The authors of this study declare that they have not got any fund assistance to execute this study from any institution, so there is no conflict of interest between the authors of the study.

\section{REFERENCES}

ahadi, H. R. (2002). Intermodal Transportation and Inland Depot Selection. Guiling, China, s.n.

Anon (n.d.). Newton - Norwegian Merchant Fleet 1939-1945.

http://www.warsailors.com/singleships/bpnewton.html. M/T B. P.

Anon (n.d.). https://wikileaks.org/syria-files/attach/104/104166_final51.docx.

Casidy, R., \& Wymer, W. (2015). The impact of brand strength on satisfaction, loyalty, and WOM: An empirical examination in the higher education sector. Journal of Brand 
ISSN: $2236-269 X$

DOI: 10.14807/ijmp.v12i5.1346

Management, 22, 117-135. doi:10.1057/bm.2015.6

Central Board Of Excise \& Customs, M. O. F. (2017). Circular No. 26/2017, s.l.:

Government of India.

Concor (n.d.). Cold Chains/Reefers. [Online]

Available at: http://www.concorindia.com/coldchains.asp

[Accessed 20 July 2018].

Concor (n.d.). Facilities \& Services: Terminal Network. [Online]

Available at: http://www.concorindia.com/terminal.aspx?tid=119\&id=16

[Accessed 24 July 2018].

Concor (n.d.). Information Systems.

Chan, K., Yim, C., \& Lam, S. (2010). Is customer participation in value creation a doubleedged sword? Evidence from professional financial services across cultures. Journal of Marketing, 74(3), 48-64. doi:10.1509/jmkg.74.3.048

Chen, C.-F., \& Chen, F.-S. (2010). Experience quality, perceived value, satisfaction, and behavioral intentions for heritage tourists. Tourism Management, 31(1), 29-35.

doi:10.1016/j.tourman.2009.02.008

Customs (n.d.). Customs Manual 2014. In: Consolidation of Cargo. s.l.:s.n.

Garnwa, P., Beresford, A., \& Pettit, S. (2009). Dry Ports: A Comparative Study of The United Kingdom and Nigeria. Transport and Communications Bulletin for Asia and the Pacific, 78(1), 40-56.

Gregory, G., Karavdic, M., \& Zou, S. (2007). The Effects of E-Commerce Drivers on Export Marketing Strategy. Journal of International Marketing, 30-57.

Gujar, G., \& Yan, H. (2010). A Comparative Perspective on Dry Ports in India, China, and Western Europe. Hongkong \& Guangzhou, s.n., 1-7.

Gururaj, B., Kumar, M. S., \& Kumar, M. A. (2016). Analysis of factors affecting the performance of exports in India. International Journal of Agriculture, Environment and Biotechnology, 9(4), 613-616.

Hicks, P. (1984). Making the most of the ICD.

Jo, M. J., \& Kim, H.-S. (2015). Development of Freight Transport Route Model by Considering Logistics Center.

Kavaliauskienè, I., Aranskis, A., \& Litvinenko, M. (2014). Consumer Satisfaction with the Quality of Logistics Services. Procedia - Social and Behavioral Sciences, 330-340.

Konings, R., Kreutzberger, E., \& Maraš, V. (2013). Major considerations in developing a hub-and-spoke network to improve the cost performance of container barge transport in the hinterland: The case of the port of rotterdam. Journal of Transport Geography, 63-73.

Lcllogistix.Com (n.d.). Providing total logistics support for the Indian leg of a major round-the-world yacht race.

Liu, S., \& Moizer, J. (2012). A hub-and-spoke model for multi-dimensional integration of green marketing and sustainable supply chain management. Industrial Marketing Management, 581-588.

Mwemezi, J. J., \& Huang, Y. (2012). Inland container depot integration into logistics networks based on network flow model: The Tanzanian perspective. African Journal of 
DOI: $10.14807 /$ ijmp.v12i5.1346

Business Management, 6(24), 7149-7157.

Nair, B. K. (2012). Evaluation Of Export Promotion Councils As Catalyst And Its Impact On Export Growth, Mumbai: D. Y. Patil University.

Nasah, C. R. J., Japang, M., \& Leng, G. S. (2012). Perception on E-Commerce Drivers and Export Marketing Strategy: A Case Study on Small and Medium Enterprises (SMEs) in Labuan Federal Territory (F.T). International Journal of eBusiness and eGovernment Studies.

Ndikom, O., \& Emeghara, G. (2012). A Critical Appraisal Of The Strategies For Improving Inland Container Deports (ICD) Performance/Productivity In Nigerian Environment.

Notteboom, T. (2008). The Relationship between Seaports and the Inter-Modal Hinterland in Light of Global Supply Chains. Paris: OECD Publishing.

Nunnally, J. C. (1978). Psychometric theory. New York: McGraw-Hill.

Padilha, F., \& Ng, A. K. Y. (2012). The spatial evolution of dry ports in developing economies: The Brazilian experience. Maritime Economics \& Logistics, 14(1), 99-121.

Pandey, P. K., Gupta, N., Pandey, P. K., \& Giri, P. (2020). The Impression of Emotional Intelligence on University Students' Academic Performance. Indian Journal of Marketing, 25-42. doi: 10.17010/ijom/2020/v50/i4/151571.

Pandey, P. K., \& Malik, P. (2017). Building Brand Equity through BTL in Water Purifier Company. Amity Journal of Marketing, 2(2), 58-83.

Parola, F., \& Giulia, A. (2010). Cold Chain In The Shipping Industry: Bulk Versus Container In The Banana Trade. World Conference on Transport Research.

Pearson, R. (2001). Malcolm McLean Dies. [Online]

Available at: https://www.washingtonpost.com/archive/local/2001/05/27/malcolm-mcleandies/050710cd-2918-4a45-a94d-7cfe2e00b772/?noredirect=on\&utm_term=.691830ca61fa [Accessed 20 July 2018].

Pettit, S. J., \& Beresford, A. K. C. (2009). Port development: from gateways to logistics hubs. Maritime Policy \& Management, 36(3), 253-267.

Ph.D. Research Bureau (2017). Role of Trade Infrastructure for Export Scheme (TIES) in Improving Export Competitiveness, s.l.: Ph.D. Chamber of Commerce and Industry.

Ratner, B. (2009). The correlation coefficient: Its values range between $+1 /-1$, or do they?. Journal of Targeting, 17(2), 139-142.

Rodrigue, J.-P., Debrie, J., Fremont, A. \& Gouvernal, E. (2010). Functions and actors of inland ports: European and North American dynamics. Journal of Transport Geography, 18(4), 519-529.

Roso, V. (2008). Factors influencing the implementation of a dry port. International Journal of Physical Distribution \& Logistics Management, 38(10), 782-798.

Roso, V., Woxenius, J., \& Lumsden, K. (2008). The dry port concept: connecting container seaports with the hinterland. Journal of Transport Geography, 1-8.

Sekaran, U., \& Bougie, R. (2016). Research Methods For Business: A Skill Building Approach. New York: Wiley.

Soinio, J., Tanskanen, K., \& Finne, M. (2012). How logistics-service providers can develop 
DOI: 10.14807/ijmp.v12i5.1346

value-added services for SMEs: a dyadic perspective. The International Journal of Logistics Management, 31-49.

Srivastava, S. K. (2013). Budget 2013-14 \& Direction for Logistics Industry.

Starzgazer (n.d.). ICD Dadri Report1, s.l.: scribd.

The World Bank (2018). LPI Global Rankings 2018. [Online]

Available at: https://lpi.worldbank.org/international/global

UNESCAP (2006). Annex I: Review of Regional Cooperation in Transport Infrastructure Development in Asia and the Pacific, s.l.: UNESCAP.

UNI (2018). India ranks 58th out of 140 economies on Global Competitiveness Index 2018: WEF. [Online]

Available at: http://www.newindianexpress.com/business/2018/oct/19/india-ranks-58th-outof-140-economies-on-global-competitiveness-index-2018-wef-1887290.html

[Accessed 02 November 2018].

United Nations (2003). The Restructuring of Railways, New York: Economic and Social Commission for Asia and The Pacific.

Veenstra, A., Zuidwijk, R., \& Asperen, E. (2012). The extended gate concept for container terminals: Expanding the notion of dry ports. Maritime Economics \& Logistics, 14(1), 1432.

WEF (2018). The Global Competitiveness Report 2018. [Online]

Available at: http://reports.weforum.org/global-competitiveness-report2018/?doing_wp_cron=1546707557.4524710178375244140625

[Accessed 02 November 2018].

Wilmsmeier, G., Monios, J., \& Lambert, B. (2011). The directional development of intermodal freight corridors in relation to inland terminals. Journal of Transport Geography, 19(6), 1379-1386.

Yim, C., Chan, K., \& Lam, S. (2012). Do customers and employees enjoy service participation ? Synergistic effects of self- and other-efficacy. Journal of Marketing, 76(6), 121-140. doi:10.1509/jm.11.0205 